\title{
Microanatomy of Axon/Glial Signaling during Wallerian Degeneration
}

\author{
Amy D. Guertin, ${ }^{2 *}$ Dan P. Zhang, ${ }^{2 *}$ Kimberley S. Mak, ${ }^{2}$ John A. Alberta, ${ }^{2}$ and Haesun A. Kim ${ }^{1}$ \\ ${ }^{1}$ Department of Biological Sciences, Rutgers University, Newark, New Jersey 07102, and 22Department of Cancer Biology, Dana-Farber Cancer Institute, \\ Boston, Massachusetts 02115
}

\begin{abstract}
How do myelinated axons signal to the nuclei of cells that enwrap them? The cell bodies of oligodendrocytes and Schwann cells are segregated from axons by multiple layers of bimolecular lipid leaflet and myelin proteins. Conventional signal transduction strategies would seem inadequate to the challenge without special adaptations. Wallerian degeneration provides a model to study axon-to-Schwann cell signaling in the context of nerve injury. We show a hitherto undetected rapid, but transient, activation of the receptor tyrosine kinase erbB2 in myelinating Schwann cells after sciatic nerve axotomy. Deconvolving microscopy using phosphorylation state-specific antibodies shows that erbB2 activation emanates from within the microvilli of Schwann cells, in direct contact with the axons they enwrap. To define the functional role of this transient activation, we used a small molecule antagonist of erbB2 activation (PKI166). The response of myelinating Schwann cells to axotomy is inhibited by PKI166 in vivo. Using neuron/Schwann cell cocultures prepared in compartmentalized cell culture chambers, we show that even transient activation of erbB2 is sufficient to initiate Schwann cell demyelination and that the initiating functions of erbB2 are localized to Schwann cells.
\end{abstract}

Key words: Wallerian degeneration; Schwann cell; neuregulin; erbB2; PKI166; demyelination

\section{Introduction}

A favored biological context for analysis of signaling from axons to myelinating cells is the sequence of events that follows damage to the sciatic nerve of the peripheral nervous system (PNS). Damage to sciatic axons triggers a stereotypical response in the downstream population of enwrapping Schwann cells termed "Wallerian degeneration." In rats, the initial event in Wallerian degeneration (degradation of myelin proteins) is observed within $12 \mathrm{~h}$ after nerve damage, and this degradation spans the distal stump of the damaged nerve (Waller, 1851; Fawcett and Keynes, 1990).

The discovery of C57BL/Wld ${ }^{\text {s }}$, a naturally occurring strain of mice with the phenotype of slow Wallerian degeneration, suggests that Wallerian degeneration is a proactive destruction process initiated by a signal from damaged axons (Thomson et al., 1991; Glass et al., 1993). The behavior of doubly myelinating Schwann cells indicates that close contact with the axon is required for delivery of this signal (Kidd and Heath, 1991). Double myelination results from displacement of a myelinating Schwann cell from axonal contact because of invasion of another Schwann

Received Sept. 10, 2004; revised Feb. 16, 2005; accepted Feb. 18, 2005.

This work was supported by National Institutes of Health Grant R01-NS45939-01 to Dr. Charles D. Stiles. We are grateful to Dr. Stiles for his support throughout this study and for discussion and comments on this manuscript. We also thank Dr. Mark Marchionni for the gift of rhGGF2 and Dr. Matthew Rasband for Caspr antibody.

*A.D.G. and D.P.Z. contributed equally to this work.

Correspondence should be addressed to Dr. Haesun A. Kim, Department of Biological Sciences, Rutgers University, 101 Warren Street, Newark, NJ 07102. E-mail: haekim@andromeda.rutgers.edu.

D. P. Zhang's present address: Program in Biological and Biomedical Sciences, Harvard Medical School, Boston, MA 02115 .

D01:10.1523/JNEUROSCI.3766-04.2005

Copyright $\odot 2005$ Society for Neuroscience $\quad$ 0270-6474/05/253478-10\$15.00/0 cell at a node. At zones of double ensheathment, the outer Schwann cell maintains its myelin sheath in the absence of axonal contact and is actually protected from myelin breakdown during Wallerian degeneration.

The neuregulin/erbB ligand-receptor system lends itself to the task of close-contact signaling between axons and myelinating cells. In the PNS, neurons express neuregulin family ligands (Ho et al., 1995). Schwann cells express erbB2 and erbB3, which heterodimerize to form functional neuregulin receptors (Vartanian et al., 1997). Certain splice isoforms of neuregulin encode transmembrane ligands that are tethered to the surface of the producing cell (Marchionni et al., 1993; Marchionni, 1995; Buonanno and Fischbach, 2001; Wang et al., 2001; Falls, 2003). Zanazzi et al. (2001) reported that recombinant neuregulin induces myelin degradation when added to neuron/Schwann cell cocultures. This observation suggests that, in addition to a variety of well documented developmental functions in the PNS (Meyer and Birchmeier, 1995; Meyer et al., 1997; Britsch et al., 1998; Morris et al., 1999; Woldeyesus et al., 1999; Michailov et al., 2004), activation of erbB2 might have additional, postdevelopmental functions in vivo by inducing Schwann cell demyelination in response to nerve injury.

In previous studies, we and others detected changes in the expression/activation state of erbB2 during Wallerian degeneration. However, these changes were noted at $4-5 \mathrm{~d}$ post-nerve injury at times well beyond the onset of Schwann cell demyelination (Carroll et al., 1997; Kwon et al., 1997). In studies described here, we demonstrate a hitherto-undetected activation of erbB2 in animals that occurs within minutes after nerve damage. Activation of erbB2 originates within the microvilli of Schwann cells, in direct contact with the axons they enwrap. 


\section{Materials and Methods}

Antibodies. For immunofluorescence staining on frozen sections or teased nerve fibers, polyclonal antibody to erbB2 (C-18; Santa Cruz Biotechnology, Santa Cruz, CA) was used at a dilution of 1:1000, and monoclonal antibodies Ab-2 and Ab-4 (Oncogene Science, Cambridge, MA) were used at 1:20. Polyclonal antibody to phospho-erbB2 (p-erbB2) (Santa Cruz Biotechnology) was used at 1:500. Monoclonal antibody to myelin basic protein (MBP) (SMI94; Sternberger Monoclonals, Lutherville, MD) was used at 1:500, and monoclonal antibody to GFAP (Sigma, St. Louis, MO) was used at 1:200. Monoclonal antibody to transferrin receptor (Zymed, San Francisco, CA) was used at 1:100, and the polyclonal antibody to platelet-derived growth factor $\beta$ receptor (PDGF $\beta \mathrm{R})$ (Upstate Biotechnology, Lake Placid, NY) was used at 1:150. Polyclonal c-jun antibody (Oncogene Science) was used at 1:2000, and monoclonal antibody Tuj1 to $\beta$-III tubulin (Sigma) was used at 1:200. Monoclonal antibody to Caspr was a gift from Dr. M. Rasband (University of Connecticut, Farmington, CT) and was used at a dilution of 1:200. Monoclonal antibody to bromodeoxyuridine (BrdU) (Boehringer Mannheim, Indianapolis, IN) was used at 1:100. Secondary antibodies were Alexa 488conjugated goat anti-mouse/rabbit and Alexa 546-conjugated goat antirabbit/mouse antibodies (Molecular Probes, Eugene, OR). For Western blot analysis, polyclonal antibodies to erbB2 and erbB3 (C-18; Santa Cruz Biotechnology) were both used at a dilution of 1:500. Monoclonal antibody to phosphotyrosine (p-Tyr) (4g10) was a gift from Dr. T. Roberts (Dana-Farber Cancer Institute, Boston, MA) and was used at a dilution of 1:10,000.

Culture media. Culture media were as follows: basal medium, DMEM with high glucose (Cellgro; Mediatech, Washington, DC) supplemented with $5 \%$ heat-inactivated horse serum (Sigma), 1\% glutamine, and penicillin/streptomycin $(0.1 \mathrm{mg} / \mathrm{ml})$; $\mathrm{CH}$ medium, basal medium supplemented with $25 \mathrm{ng} / \mathrm{ml}$ nerve growth factor (NGF 2.5S; Upstate Biotechnology) and $20 \mathrm{ng} / \mathrm{ml}$ BDNF (Peprotech, Rocky Hill, NJ); CH-AraC medium, $\mathrm{CH}$ medium supplemented with $0.24 \mu \mathrm{g} / \mathrm{ml}$ cytosine $\beta$-D-arabinofuranoside; SC medium, DMEM supplemented with $10 \%$ heatinactivated fetal bovine serum (FBS) (HyClone, Logan, UT) and penicillin/streptomycin $(0.1 \mathrm{mg} / \mathrm{ml}) ;$ SC-VitC medium, SC medium supplemented with $25 \mathrm{ng} / \mathrm{ml} \mathrm{NGF}$ and $50 \mu \mathrm{g} / \mathrm{ml}$ ascorbic acid (Sigma); N2 medium, 1:1 ratio of DMEM and F-12 supplemented with Na selenite (5 ng/ml), putrescine $(16 \mu \mathrm{g} / \mathrm{ml})$, progesterone $(125 \mathrm{ng} / \mathrm{ml})$, apotransferrin $(0.2 \mathrm{mg} / \mathrm{ml})$, insulin $(0.4 \mu \mathrm{g} / \mathrm{ml})$, and NGF $(25 \mathrm{ng} / \mathrm{ml})$.

Establishment of neuron-Schwann cell compartmentalized coculture system. Compartmentalized chambers (Campenot chambers) were assembled onto collagen-coated $35 \mathrm{~mm}$ culture dishes as described previously (Campenot, 1982). Before plating cells, the side chambers were filled with basal medium for $24 \mathrm{~h}$ to check for any leaks between the compartments (day 0). On day 1, dissociated dorsal root ganglia (DRGs) were prepared from embryonic day 14.5 rat embryos as described previously (Eldridge et al., 1987). In each middle compartment, five to six dissociated DRGs were plated in a volume of $40 \mu \mathrm{l}$ in $\mathrm{CH}$ medium using a $100 \mu \mathrm{l}$ glass syringe with a 20-gauge luer stub adapter tip (Becton Dickinson, Mountain View, CA). On day 2, the side chambers and space outside of the Teflon divider were also filled with $\mathrm{CH}$ medium. Starting on day 7 , cultures were cycled between $\mathrm{CH}-\mathrm{Ara} \mathrm{C}$ and $\mathrm{CH}$ media to kill off any dividing non-neuronal cells. Meanwhile, axons continued to grow into the side compartments. On day 16, Schwann cells prepared from neonatal rat sciatic nerves (Brockes et al., 1979) were seeded onto axons in the side compartments $\left(1 \times 10^{5}\right.$ cells/compartment $)$ in SC medium supplemented with NGF. The next day, the cells were switched to N2 medium. Six days later (day 23), cells were put into SC-Vit C medium to initiate Schwann cell myelination (Eldridge et al., 1987). Cells were fed with fresh medium every other day. Within 4 weeks, unidirectional myelinated axons were formed along the tracks in the side compartments. Before use, chambers were subjected to a leak test by using a tracking dye for visual detection as described previously (Esper and Loeb, 2004).

Sciatic nerve injury in rats and PKI166 administration. Adult female Sprague Dawley rats (250-280 g) were anesthetized with Avertin (125$250 \mathrm{mg} / \mathrm{kg}$, i.p.). Using aseptic technique, an incision was made on the upper right thigh to expose the sciatic nerve. The nerve was cut $\sim 1 \mathrm{~cm}$ distal to the sciatic notch, and the wound was closed. At various times after the sciatic nerve cut, animals were killed, and nerves were harvested and processed for different applications (see below, Immunofluorescence staining; Immunoprecipitation and Western blot analysis). For administration of PKI166 (a generous gift from Novartis Pharmaceuticals, Basel, Switzerland), the drug was dissolved in $200 \mu$ l of DMSO (50 $\mathrm{mg} / \mathrm{kg}$ body weight) and injected intraperitoneally into the animals.

Preparation of sciatic nerve sections and teased nerve fibers. For preparation of frozen sections, nerves were removed from the animals, fixed in $4 \%$ paraformaldehyde for $3-4 \mathrm{~h}$, and then infused in $30 \%$ sucrose at $4^{\circ} \mathrm{C}$ overnight. Tissues were then embedded in OCT embedding media (TissueTek), and the frozen $12 \mu \mathrm{m}$ cryostat sections were cut and mounted on coated glass slides. For teased nerve fiber preparation, nerves were fixed in $4 \%$ paraformaldehyde for $10 \mathrm{~min}$, washed in Tris-buffered saline (TBS), and the perineurium was removed. Nerves were teased first with a 30 -gauge needle and then with a sharpened tungsten needle. A few teased fibers were transferred into a drop of TBS on a coated glass slide and pulled to stretch them out on the slide. Nerve fibers were dried overnight at room temperature and stored at $-80^{\circ} \mathrm{C}$ until ready to use for immunostaining. When teased nerve fibers were prepared for $\mathrm{p}$-erbB2 staining, a $6 \mathrm{~mm}$ nerve segment was removed from the cut site before teasing the nerve. Paraformaldehyde solution and TBS were kept on ice and supplemented with $1 \mathrm{~mm}$ sodium orthovanadate and $1 \mathrm{~mm}$ sodium fluoride.

Schwann cell proliferation assay (bromodeoxyuridine incorporation) in vivo and in vitro. For in vivo nerve injury-induced Schwann cell proliferation, sciatic nerves were cut. After $48 \mathrm{~h}$, rats were injected with BrdU ( $50 \mathrm{mg} / \mathrm{kg}$ body weight) prepared in PBS. One hour later, the animals were killed, and frozen nerve sections were prepared as described above. Sections were fixed in cold methanol for $10 \mathrm{~min}$, rehydrated in PBS for 3 min, and then treated with $2 \mathrm{~N} \mathrm{HCl}$ for $15 \mathrm{~min}$ at $37^{\circ} \mathrm{C}$. Cells were washed three times in $0.1 \mathrm{~m}$ borate buffer $(\mathrm{pH} 8.5)$ over a $10 \mathrm{~min}$ period and then washed three times in PBS in the same manner. Sections were incubated in blocking solution (5\% normal goat serum supplemented with $0.2 \%$ Triton X-100) for $30 \mathrm{~min}$ and incubated with monoclonal BrdU antibody prepared in blocking solution for $1 \mathrm{~h}$ at room temperature. Cyanine 2 -conjugated goat anti-mouse secondary antibody was added for $1 \mathrm{~h}$, and before mounting, cells were incubated with $4^{\prime}, 6^{\prime}$-diamidino-2phenylindole (DAPI) for $1 \mathrm{~min}$ to visualize nuclei.

For Schwann cell proliferation in the compartmental culture system, myelinated axons in the side compartments were cut using a razor blade. After $24 \mathrm{~h}, \operatorname{BrdU}(10 \mu \mathrm{M})$ was added to the cultures. Two hours later, cultures were fixed in cold methanol and immunostained for BrdU as described above.

Immunofluorescence staining. Sections or teased nerve fibers were rehydrated in TBS for $3 \mathrm{~min}$, and then fixed in 4\% paraformaldehyde for 20 min. After washing with TBS, samples were permeabilized in blocking solution (5\% normal goat serum plus $0.1 \%$ Triton X-100) for $30 \mathrm{~min}$, and then incubated with primary antibodies (see above, Antibodies). After washing with TBS, samples were incubated with secondary antibodies for $45 \mathrm{~min}$. Nuclei of cells were visualized by staining with DAPI. For p-erbB2 detection, immunostaining was done as above except samples were fixed for $5 \mathrm{~min}$ in $4 \%$ paraformaldehyde and permeabilized in $20 \%$ FBS plus $1 \%$ BSA plus $0.1 \%$ Triton X-100. For MBP, samples were fixed in $4 \%$ paraformaldehyde for $20 \mathrm{~min}$ and permeabilized in cold methanol for $15 \mathrm{~min}$ followed by blocking in 5\% normal goat serum supplemented with $0.1 \%$ Triton X-100.

Immunoprecipitation and Western blot analysis. Rat sciatic nerves were harvested at different time points after nerve transection, and the proximal and distal nerves were harvested. Quickly, $6 \mathrm{~mm}$ nerve segments from the cut site were removed from both the distal and proximal nerves, perineurium was removed, and the remainder of the nerves was frozen in liquid nitrogen. For each immunoprecipitation, four sciatic nerves were used. On ice, the frozen nerves were homogenized with 20 strokes in a Dounce homogenizer in $500 \mu \mathrm{l}$ of lysis buffer (20 mM Tris, pH 7.4, 1\% NP-40, 10\% glycerol, 2.5 mm EGTA, 2.5 mм EDTA, 1 mm sodium orthovanadate, $1 \mathrm{~mm}$ sodium fluoride, $1 \mathrm{~mm}$ PMSF, $10 \mu \mathrm{g} / \mathrm{ml}$ aprotinin, and $20 \mu \mathrm{M}$ leupeptin). The lysates were cleared by centrifugation at $12,000 \times g$ for $15 \mathrm{~min}$, and the supernatants were collected. For immunoprecipitation, $1 \mathrm{mg}$ of each lysate was incubated with $1 \mu \mathrm{g}$ of primary 
antibody (erbB2 or PDGF $\beta$ R) (see above, Antibodies) at $4^{\circ} \mathrm{C}$ for $1 \mathrm{~h}$. Fifty microliters of protein A-Sepharose beads, which had been blocked previously in $10 \%$ BSA, were added to the lysates and incubated for another $1 \mathrm{~h}$. Immunoprecipitates were then size fractionated on $7 \%$ SDSpolyacrylamide gels, transferred onto polyvinylidene difluoride membranes and immunoblotted with p-Tyr antibody or growth factor receptor antibodies (see above, Antibodies).

Preparation of sciatic nerve semithin sections and toluidine blue staining. Nerves were harvested and fixed in $4 \%$ paraformaldehyde and 2\% glutaraldehyde in TBS for 4-6 h. After rinsing the nerves in TBS, they were placed into $1 \%$ osmium tetroxide-1.5\% potassium ferrocyanide for $2 \mathrm{~h}$, and then into $4 \%$ uranyl acetate in maleate buffer, $\mathrm{pH}$ 5.2, for $1 \mathrm{~h}$. Nerves were dehydrated in a series of ethanol $(50,80$, and $100 \%)$ and then embedded in Taab 812 epon resin (Marivac, St. Laurent, Quebec, Canada). Sections were cut $(0.5 \mu \mathrm{m})$, picked up onto glass slides, dried on the hot plate, and then stained with $1 \%$ toluidine blue in $1 \%$ sodium borate buffer. Sections were then viewed under the light microscope.

\section{Results}

erbB2 is rapidly and selectively activated in animals after nerve injury

The sciatic nerve of adult female Sprague Dawley rats was transected as previously described (Kwon et al., 1997). At timed intervals after surgery, animals were killed, and the nerve stumps were harvested for biochemical analysis. When damaged nerves are sampled at low resolution (daily intervals), erbB2 is upregulated and also activated; however, as noted previously, these changes are seen only at late stages of the Wallerian response (Fig. $1 A)$. Sampling at high resolution (minutes after surgery) gives a different answer. As shown in Figure $1 B$, nerve damage actually triggers an acute and transient activation of erbB2 at much earlier times. The response of erbB2 is readily detectable within $10 \mathrm{~min}$ and much attenuated by $3 \mathrm{~h}$ postaxotomy. PDGF and PDGF $\beta \mathrm{R}$ are expressed on axons and Schwann cells, respectively, and have been suggested to play a role in axon-Schwann cell interactions (Hardy et al., 1992; Eccleston et al., 1993). Despite its presence in Schwann cells, PDGF $\beta$ R activation is not detected in distal nerves after axotomy (Fig. 1C).

In Schwann cells, neuregulin-induced activation of erbB2 requires formation of an erbB2/erbB3 heterodimer (Burden and Yarden, 1997). Accordingly, we asked whether erbB3 participates in erbB2 activation induced by axotomy. As shown in Figure $1 D$, an increased level of erbB3 activation is detected in the distal stump within $1 \mathrm{~h}$ after axotomy. The mitogen-activated protein kinase (MAPK) functions as a downstream signal generator for activated neuregulin receptors (Marte et al., 1995; SeppLorenzino et al., 1996; Carroll et al., 1997; Grasso et al., 1997; Pinkas-Kramarski et al., 1998; Baliga et al., 1999). MAPK also plays a role in neuregulin-induced Schwann cell demyelination in culture (Harrisingh et al., 2004). As shown in Figure 1 E, MAPK is activated within $20 \mathrm{~min}$ after axotomy. In contrast to erbB2, however, activation of MAPK is sustained for as long as $24 \mathrm{~h}$ after surgery.

Collectively, these data show that erbB2 is rapidly and selectively activated in the distal stump of damaged nerves. The neuregulin coreceptor erbB3 participates in this rapid activation. Activation peaks at between 30 and $60 \mathrm{~min}$ after nerve damage and is much attenuated in the hours thereafter. The time course of MAPK activation appears to be more sustained than the activation of erbB2 noted in Figure $1 A$. As we will show below (see Fig. 3 and Discussion), this paradox is resolved by monitoring erbB2 activation at the cellular level.
A.

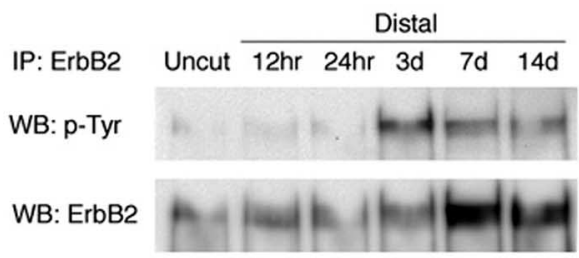

B

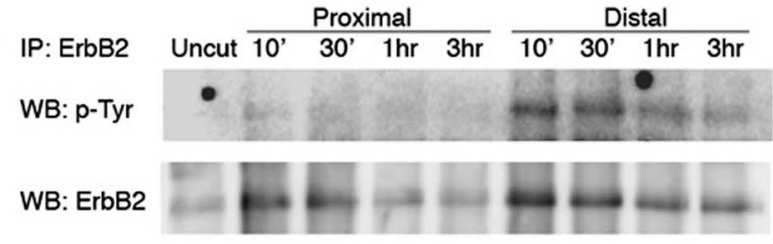

C.
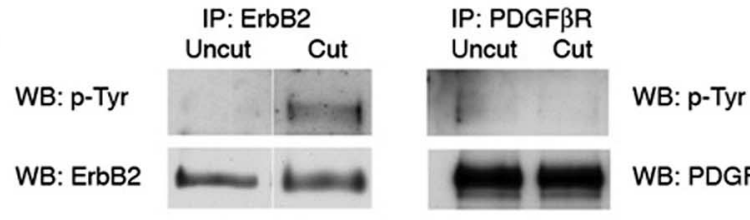

D.

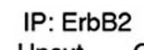

WB: $p$-Tyr Uncut Cut

WB: ErbB2
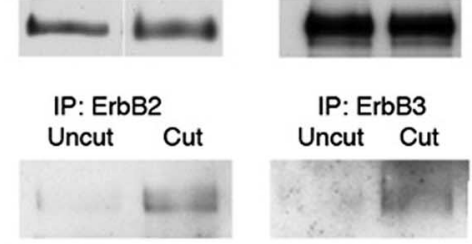

WB: PDGF $\beta R$

E.
p-MAPK
MAPK

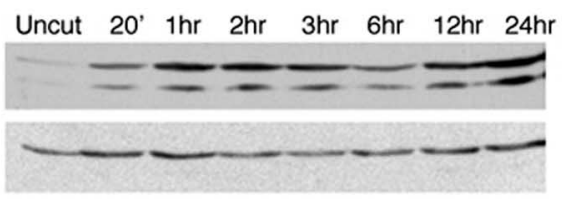

Figure 1. Early and late activation of erbB2 after axotomy. A, Late activation of erbB2. Rat sciatic nerve was transected. At times indicated, the distal stumps were harvested. Nerve lysates were immunoprecipitated with antibodies to erbB2, size fractionated by SDS gel electrophoresis, and immunoblotted with antibodies to p-Tyr or erbB2. As reported previously (Carroll et al., 1997; Kwon et al., 1997), erbB2 protein is overexpressed and also activated at late stages of Wallerian degeneration (3-14 d) at times when Schwann cells have begun to proliferate. IP, Immunoprecipitation; WB, Western blot. $\boldsymbol{B}$, Early activation of erbB2 (as above, except the nerve stumps were sampled on a timescale of minutes rather than days). As indicated, erbB2 is activated quickly (within $10 \mathrm{~min}$ ) in the distal stump but not in the proximal stump of axotomized nerves. Activation is maximal between 30 and 60 min after axotomy and is then attenuated. The experiment shown is representative of four replicate experiments. The apparent increase in total erbB seen here at early times in the distal stumps is attributable to experimental variation and is not seen in other experiments. C, Early activation of erbB2 is selective. Nerve lysates from uncut and $1 \mathrm{~h}$ postaxotomized distal nerves were immunoprecipitated with erbB2 or PDGF $\beta R$ antibodies and immunoblotted with $\mathrm{p}$-Tyr antibody. The blots were reused and immunoblotted with erbB2 or PDGF $\beta$ R antibodies. $\boldsymbol{D}$, The neuregulin coreceptor erbB3 participates in the early activation response. Nerve lysates were immunoprecipitated with anti-erbB2 or anti-erbB3 and immunoblotted with antibodies to p-Tyr, erbB2, or erbB3, as indicated. As shown, both erbB2 and erbB3 are activated after nerve injury in the distal stump. $\boldsymbol{E}$, Activation of MAPK in distal stumps after axotomy.

\section{Receptor tyrosine kinases are localized to the microvilli of myelinating Schwann cells}

Because Wallerian degeneration is initiated only within Schwann cells that contact the axon (Kidd and Heath, 1991), we used immunostaining techniques and deconvolving microscopy to determine the subcellular localization of erbB2 in myelinated axons. In teased nerve fiber preparations of rat sciatic nerve, we occasionally noted weak erbB2 immunostaining at the perinu- 

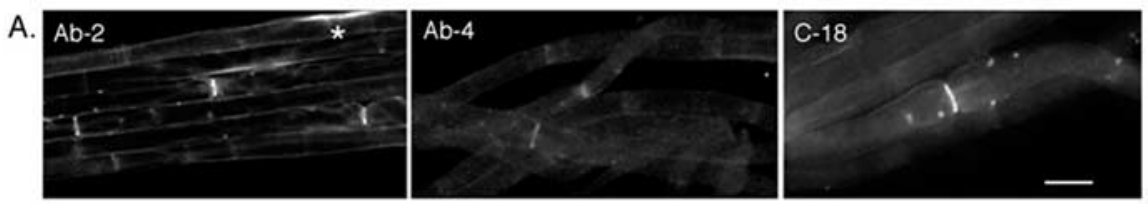

B.
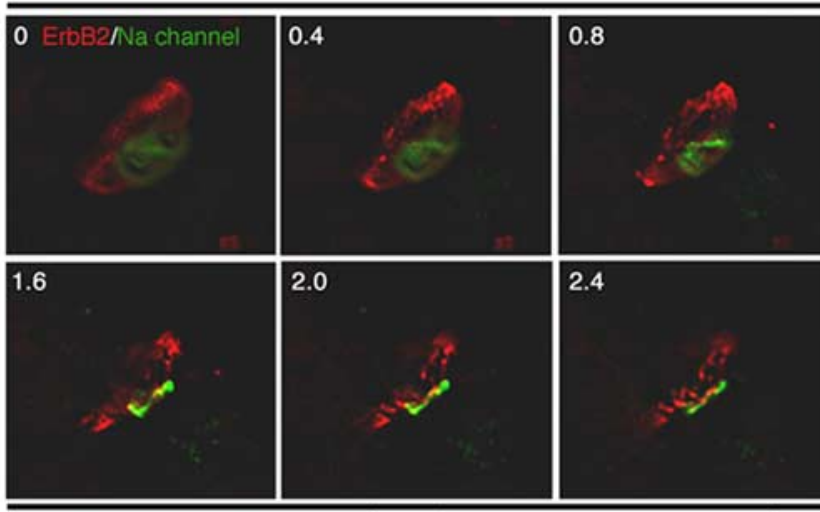

C
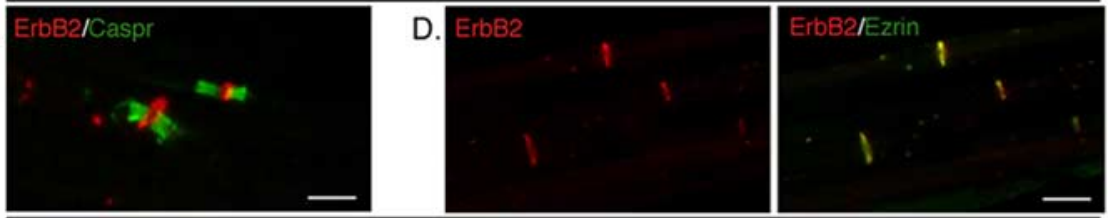

E.
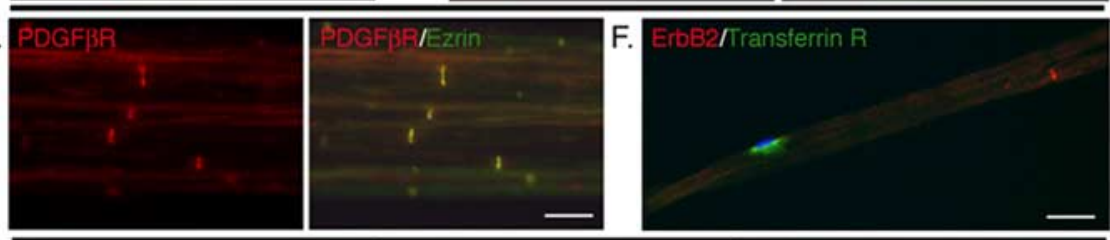

G.
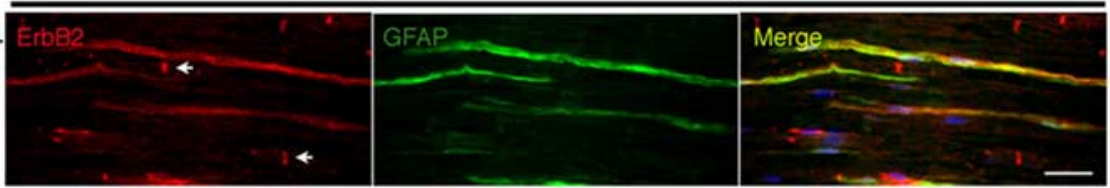

Figure 2. Receptor tyrosine kinases are selectively expressed at the nodal regions of myelinating Schwann cells. $\boldsymbol{A}$, Lowmagnification image of erbB2 expression in rat sciatic nerves. Teased preparations of rat sciatic nerve were immunostained with three different antibody preparations targeted to erbB2 (see Materials and Methods). All three antibodies decorate the nodal regions of the axons. In occasional cells, some perinuclear staining is also seen (*). Scale bar, $10 \mu \mathrm{m}$. $\boldsymbol{B}$, Nodal staining pattern reflects erbB2 in Schwann cells. Deconvolved images of sequential $0.4 \mu \mathrm{m}$ optical sections (as numbered from top left) of a nodal region of a teased nerve immunostained with antibodies to sodium channel (green) and erbB2 (red). The erbB2 immunofluorescence surrounds the sodium channel, indicating that erbB2 is localized in the nodal region of the myelinating Schwann cell. Scale bar, $5 \mu \mathrm{m}$. C, Within Schwann cells, erbB2 is localized to the nodes rather than the paranodes. A teased nerve preparation immunostained with antibodies to erbB2 and Caspr. Expression of erbB2 is flanked by Caspr expression in the paranodes. D, Within the nodes, erbB2 is localized to the microvilli of myelinating Schwann cells. A frozen section of rat sciatic nerve was immunostained with antibodies to erbB2 (red) and Ezrin (green). Expression of erbB2 colocalizes with that of Ezrin, indicating that erbB2 protein is expressed on microvilli of Schwann cells. $\boldsymbol{E}$, The PDGF $\beta$ R is also localized to the microvilli [as in $\boldsymbol{D}$ except antibodies were to Ezrin (red) and PDGF $\beta R$ (green)]. Scale bars: $\boldsymbol{C}-\boldsymbol{E}, 15 \mu \mathrm{m} . \boldsymbol{F}$, A nutrient transport receptor (transferrin) is targeted to the perinuclear regions of myelinating $S$ chwann cells [as in $\boldsymbol{D}$ and $\boldsymbol{E}$ except that antibodies are directed to the transferrin receptor (green) or erbB2 (red)]. A nucleus of myelinating Schwann cells are indicated by DAPI staining (blue). G, Diffuse expression of erbB2 in nonmyelinating Schwann cells. Frozen sections of rat sciatic nerve were immunostained with antibody against GFAP (green) to visualize nonmyelinating Schwann cells. In GFAP-positive nonmyelinating Schwann cells, erbB2 expression (red) is distributed along the cytoplasm. Nodal expression of erbB2 in myelinating Schwann cells is also shown (arrows). Scale bars: $F, \mathbf{G}, 30 \mu \mathrm{m}$

clear region and the outer membrane of myelinating Schwann cells; however, as indicated in Figure $2 \mathrm{~A}$, we consistently detected erbB2 preferentially localized to the nodal region of the myelinating Schwann cells. This pattern of erbB2 localization was seen with three different antibody preparations targeted to erbB2 (see Materials and Methods).

Optical sections through a node of Ranvier, immunostained using erbB2 and sodium channel antibodies to mark the axon, show erbB2 protein localized to a ring that surrounds the axon

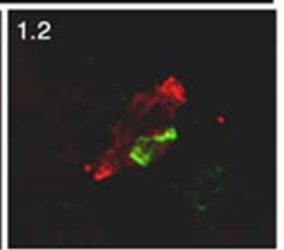

but is not within the axon (Fig. $2 B$ ). When double-immunostained with antibodies to a paranodal protein Caspr (Einheber et al., 1997; Menegoz et al., 1997), erbB2 expression is seen at the node flanked by Caspr expression (Fig. 2C). erbB2 also colocalizes with Ezrin, a protein expressed on microvilli of myelinating Schwann cells (Fig. 2D) (Melendez-Vasquez et al., 2001; Scherer et al., 2001).

The PDGF $\beta \mathrm{R}$ is also localized to the nodal region of myelinating Schwann cells and is colocalized with Ezrin (Fig. 2E). Notably, however, the transferrin receptor, a single-pass, transmembrane iron transporter with no known function in axon-Schwann cell interactions, is localized to the perinuclear region of myelinating Schwann cells (Fig. 2F). Therefore, the nodal region is not a default compartment for localization of single-pass receptors in myelinating Schwann cells. Expression of erbB2 was also examined in nonmyelinating Schwann cells of a rat sciatic nerve. Unlike myelinating Schwann cells, the GFAP-positive nonmyelinating Schwann cells showed diffuse expression of erbB2 over their cytoplasmic membrane (Fig. $2 G$ ).

erbB2 activation is detected at the nodal regions of myelinating Schwann cells

To visualize the location of erbB2 at its activation state in myelinating Schwann cells, we used phosphorylation statespecific antibody to erbB2 (p-erbB2). The specificity of the antibody was confirmed by immunostaining on cultured Schwann cells stimulated with neuregulin. erbB2 activation is readily seen in Schwann cells within 5 min of neuregulin treatment, but not in the Schwann cells left untreated (Fig. 3A). We then used the antibody to locate erbB2 activation in rat sciatic nerve after nerve injury. Within $1 \mathrm{~h}$ after axotomy, erbB2 activation was detected both at the nodal and the paranodal regions of myelinating Schwann cells (Fig. 3 B, C). A three-dimensional reconstruction of the immunostaining using deconvolving microscopy shows a punctate pattern of erbB2 staining at the nodal region that sometimes extends out to the outer membrane of a myelinating Schwann cell (Fig. $3 D)$. In rare instances $(<1 \%$ of the myelinating cells examined), erbB2 activation was also detected at the perinuclear regions of myelinating Schwann cells (data not shown). In marked contrast to axotomy-induced activation of erbB2 in myelinating Schwann cells, erbB2 activation in nonmyelinating Schwann cells is detected both in the uncut and in axotomized nerve (data not shown).

To quantitate the localized activation of erbB2 in myelinating Schwann cells, we scored the number of nodes, marked by Ezrin expression, that are also positive for p-erbB2 staining (Fig. $3 E$ ). 
A.

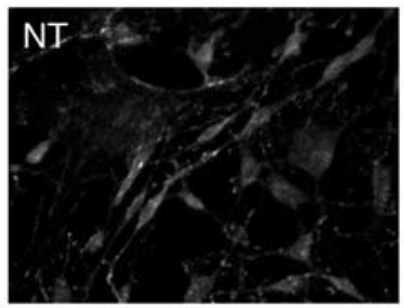

B. Uncut
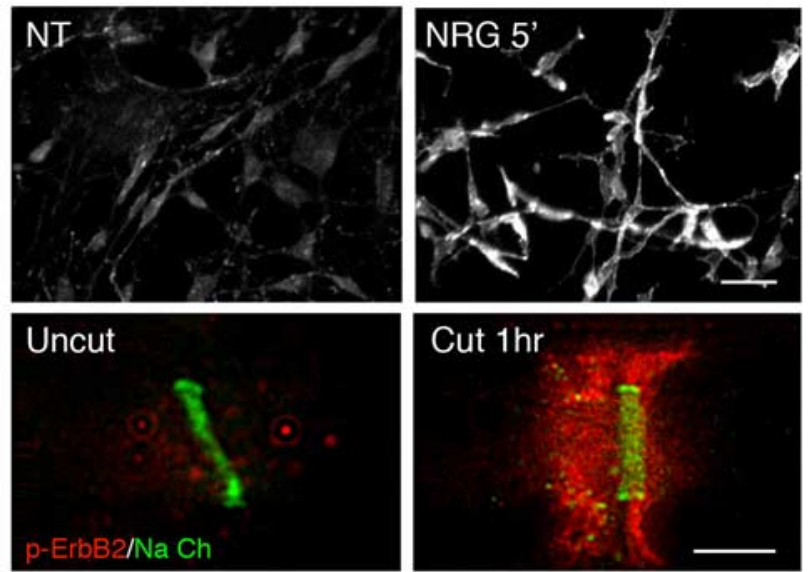

a

C. $a$
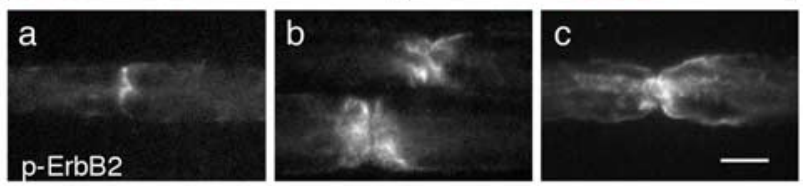

D.

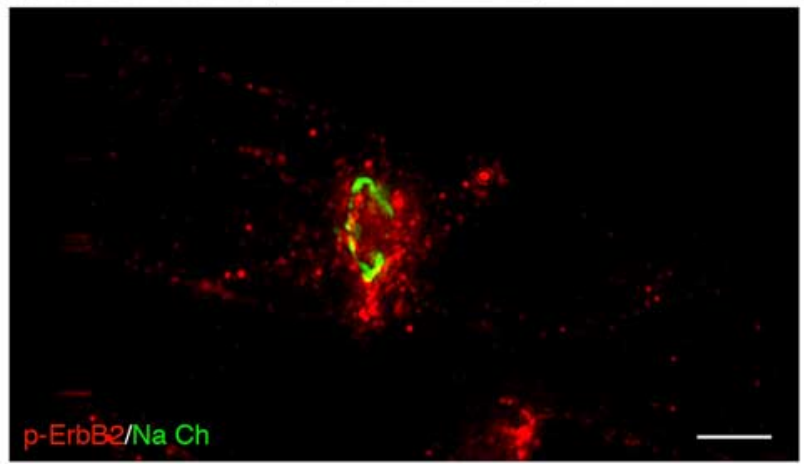

E.

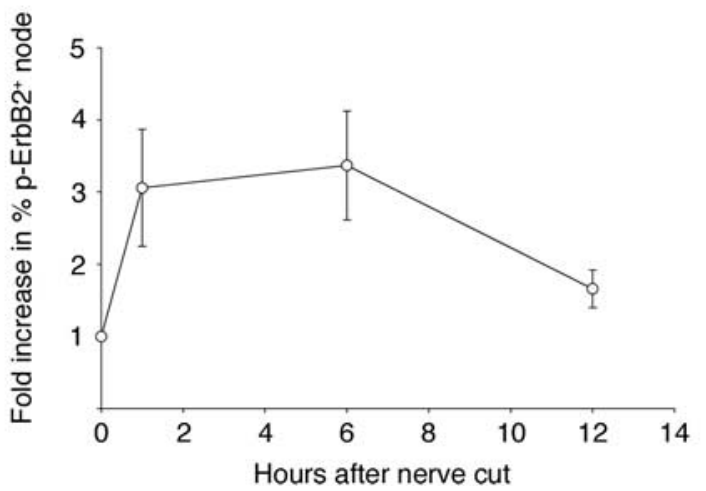

Figure 3. Rapid activation of erbB2 at the nodal/paranodal regions in myelinating Schwann cells after nerve injury. $\boldsymbol{A}$, Immunostaining with phosphospecific antibody detects activation of erbB2. Cultured rat Schwann cells were stimulated with neuregulin $(10 \mathrm{ng} / \mathrm{ml})$ for $5 \mathrm{~min}$ and then immunostained with a phosphorylation state-specific antibody to erbB2 (p-erbB2). Cells that were left untreated (NT) were used as a control. Positive immunoreactivity is only seen in cells stimulated with neuregulin. Scale bar, $10 \mu \mathrm{m}$. B, Rapid activation of erbB2 at the node/ paranode regions in myelinating Schwann cells after nerve injury. Teased nerve preparations of an intact nerve (Uncut) and a distal stump (Cut $1 \mathrm{~h}$ ) were harvested $1 \mathrm{~h}$ after axotomy. Nerves were immunostained using p-erbB2 (red) and sodium channel $(\mathrm{Na} \mathrm{Ch}$ ) (green) antibodies to mark the node. Deconvolved microscope images show a punctate pattern of p-erbB2 staining extending outward from the nodal regions of myelinating $S$ chwann cells in cut nerves but not in uncut samples. Scale bar, $5 \mu \mathrm{m}$. C, Different patterns of $\mathrm{p}$-erbB2 staining on myelinating Schwann cells after nerve injury. Pictures show $\mathrm{p}$-erbB2 immunostaining on teased nerve fibers prepared $3 \mathrm{~h}$ after nerve injury. Activated erbB2 is detected at the nodal $(\boldsymbol{a})$ and paranodal $(\boldsymbol{b})$ regions and on the outer membrane of myelinating Schwann cells (c). Scale bar, $10 \mu \mathrm{m} . \boldsymbol{D}$, Punctate appearance of $p$-erbB2 after nerve injury (as in $\boldsymbol{B}$ except the image shows a tangential section through the nodal region of a distal stump $S$ chwann cell at $1 \mathrm{~h}$ after axotomy). The node is indicated by immunostaining for sodium channel (green). Puncta of activated erbB2 extend
These immunostaining data confirm the immunoblot assays in showing that erbB2 activation is rapid. Notably, however, by the metric of p-erbB2-positive nodes, the initial wave of erbB2 activation persists for longer periods of time than would be suggested by immunoblot assays (Fig. $1 B$ ). The time course of erbB2 activation as measured at the cellular level is in good accord with the time course of MAPK activation shown in Figure $1 E$.

\section{Inhibition of erbB2 activation blocks the Schwann cell response to nerve injury in vivo}

A small molecule inhibitor, ATP mimetic PKI166, blocks erbB2 activation both in vitro and in vivo (Traxler et al., 2001). In cultured Schwann cells, neuregulin-induced erbB2 activation is inhibited by PKI166 in a dose-dependent manner. Activation of MAPK is also completely blocked by PKI166, but the drug has no effect on PDGF $\beta$ R activation (Fig. $4 A$ ). As shown in Figure $4 B$, PKI166 is also capable of penetrating the peripheral nerves to inhibit the activation of erbB2 that is induced by axotomy. Accordingly, we used PKI166 to determine the requirement of erbB2 activation on the Schwann cell response to nerve injury in vivo.

When Schwann cells undergo demyelination, the cells accumulate debris of myelin sheath, or so called "ovoids," inside the cytoplasm. When immunostained with antibody to MBP, these ovoids can be distinguished easily by their unique morphology and the intensity of the staining (Fig. 4C, Cut, inset). Therefore, we used ovoid formation as a measure for determining the degree of Schwann cell demyelination caused by nerve injury. In vehicletreated animals (Cut-DMSO), a high number of ovoids were detected in the distal stump of damaged nerves within $2 \mathrm{~d}$. In contrast, ovoid formation was greatly reduced in animals treated with PKI166 (Cut-PKI166). Figure 5 shows the histology of the nerves harvested from vehicle- and PKI166-treated animals $2 \mathrm{~d}$ after axotomy. In vehicle-treated animals, nerve injury-induced Schwann cell demyelination (shown by separation and unwinding of compact myelin layers) is clearly seen. In PKI166-treated animals, this demyelination is retarded. In some cases, compact myelin sheaths are retained even in the absence of the axons.

Demyelination is followed by Schwann cell proliferation during Wallerian degeneration. The effect of PKI166 on Schwann cell proliferation was assessed by BrdU incorporation into Schwann cells after nerve injury. As shown (Fig. 4D), a significant fraction of the Schwann cells in vehicle-treated animals were labeled by BrdU. This BrdU labeling was almost completely eliminated in animals treated with PKI166. Therefore, Schwann cell responses that follow nerve injury, demyelination, and proliferation, are inhibited in animals treated with PKI166.

from the nodal region toward the outer plasma membrane of the myelinating Schwann cell. Scale bar, $5 \mu \mathrm{m}$. $\boldsymbol{E}$, Quantitation of erbB2 activation in distal stump using immunostaining. Teased nerve fibers prepared at various hours after axotomy were immunostained for Ezrin and p-erbB2. The total numbers of nodes, marked by Ezrin expression, and p-erbB2-positive nodes and paranodes were counted. Increase in erbB2 activation at each time point was determined by calculating fold increase in percentage of $\mathrm{p}$-erbB2 nodes in axotomized nerve compared with the control (uncut). For each data point, 100-200 nodes were counted. The mean values and SEM were determined from three independent experiments. There is a significant increase in p-erbB2-positive nodes within $1 \mathrm{~h}$ after axotomy. This increase is sustained for $6 \mathrm{~h}$ and is still discernible (although diminished) at $12 \mathrm{~h}$. In one experiment not shown, we immunostained for $\mathrm{p}$-erbB2 at $24 \mathrm{~h}$ after axotomy. At this late time point, no positive $\mathrm{p}$-erbB2 staining was detected. 
A.

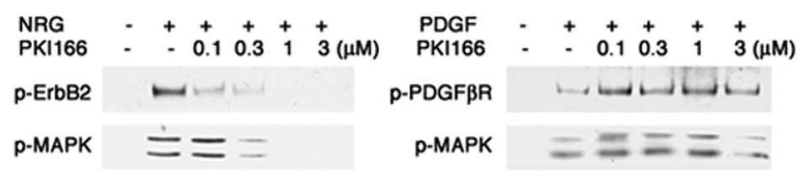

B.

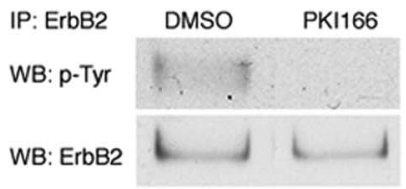

C.
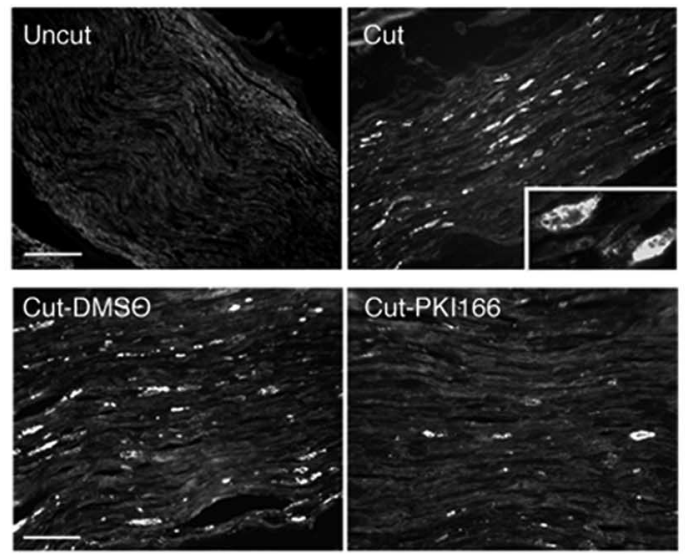

D.
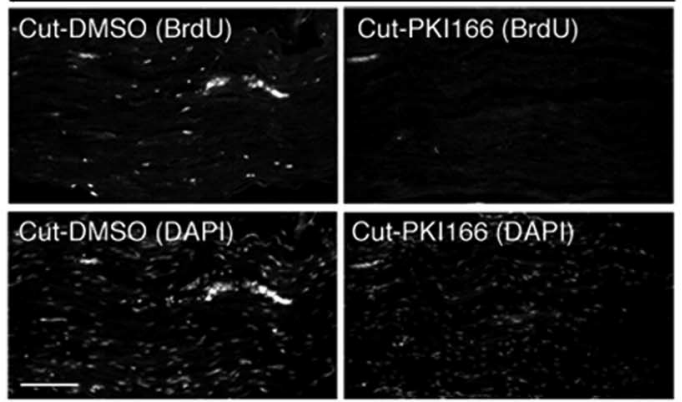
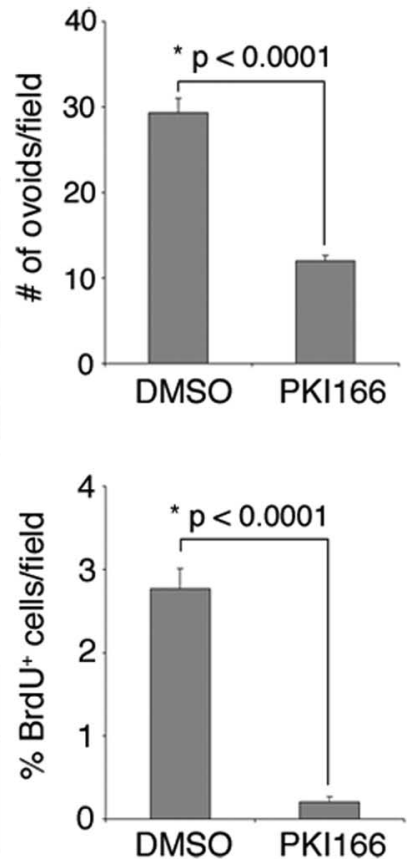

Figure 4. PKI166 blocks Schwann cell response to nerve injury in vivo. A, PKI166 is a selective inhibitor of erbB2 activation. Primary rat Schwann cells were pretreated with various concentrations of PKI166 for $15 \mathrm{~min}$ and then stimulated with neuregulin (NRG) $(30 \mathrm{ng} / \mathrm{ml})$ or PDGF $(30 \mathrm{ng} / \mathrm{ml})$ for $5 \mathrm{~min}$. Cell lysates were prepared and subjected to immunoprecipitation using antibodies to erbB2 or PDGF $\beta$ R, followed by immunoblotting using antibodies to $\mathrm{p}$-Tyr. Activation of the downstream signaling protein MAPK was determined by immunoblotting using p-MAPK antibody. As indicated, PKI166 inhibits activation of erbB2 and also MAPK in response to neuregulin but has no effect on PDGF $\beta$ R activation or PDGF-induced signaling events. $\boldsymbol{B}$, PKI166 inhibits axotomy-induced erbB2 activation in vivo. Thirty minutes before axotomy, rats were injected intraperitoneally with PKI166 or solvent control. One hour after axotomy, distal stump nerves were harvested. Nerve lysates were immunoprecipitated with antibody to erbB2 and immunoblotted with p-Tyr antibody. IP, Immunoprecipitation; WB, Western blot. C, Ovoids of myelin are a convenient metric for demyelination. Frozen sections of uncut or axotomized sciatic nerves were immunostained at $2 \mathrm{~d}$ after surgery with antibody to MBP. Top, In uncut nerve, the myelinated axons are evenly stained with the antibody. In a cut nerve, more intense staining on spherical clumps of myelin debris (ovoids) is visible. Inset, Higher magnification of an ovoid stained with anti-MBP antibody. Scale bar, $50 \mu \mathrm{m}$. Bottom, Ovoid formation is retarded in PKI166-treated animals. Rats were injected with PKI166 or solvent control as in $\boldsymbol{B}$. After axotomy, rats were treated with a daily injection of PKI166 (Cut-PKI166) or solvent control (Cut-DMSO) for $2 \mathrm{~d}$. Distal nerves were harvested and immunostained for MBP. Scale bar, $30 \mu \mathrm{m}$. D, Schwann cell proliferation is blocked in animals treated with PKI166 after nerve injury. Surgery and drug treatments are the same as in $\boldsymbol{B}$. Schwann cell proliferation in control and axotomized rats was visualized by injecting rats with BrdU at $2 \mathrm{~d}$ after axotomy and then immunostaining with anti-BrdU antibody. Bottom panels show Schwann cell nuclei stained with DAPI. Scale bar, $50 \mu \mathrm{m}$. Quantifications of the experiments in $\boldsymbol{C}$ and $\boldsymbol{D}$ are shown on the right. The mean values and SEM were calculated from three independent experiments with each experiment containing data obtained from at least $20-30$ random fields. Asterisks indicate statistical significance was determined by ANOVA test. not show that transient activation is sufficient to initiate the demyelination response. To determine whether transient activation of erbB2 is sufficient to initiate Schwann cell demyelination, we turned to neuron/Schwann cell cocultures (Zanazzi et al., 2001). As shown by pulse-chase experiments (Fig. 6), transient activation of erbB2 by recombinant neuregulin is sufficient to induce Schwann cell demyelination. At the concentration used in these studies $(30 \mathrm{ng} / \mathrm{ml}), 1$ h of neuregulin treatment was sufficient to obtain a halfmaximal demyelination response of Schwann cells.

\section{An in vitro model for}

Wallerian degeneration

Another limitation of the animal data shown in Figure 4 is that the experiment with PKI166 does not document a function of erbB2 on Schwann cells. To localize the role of erbB2 activation, we adapted the Campenot compartmentalized chamber culture system (Campenot, 1977, 1982) to the study of Wallerian degeneration. The protocol for preparing these cultures is illustrated in Figure 7. As indicated, myelinated axons prepared in these cocultures are neatly aligned so that multiple axons can be severed in synchrony with a single stroke of a razor blade. Moreover, Schwann cells on the axons and neuronal cell bodies in these compartmental cocultures lend themselves separately to genetic and pharmacological intervention.

As indicated in Figure 8, the in vivo sequence of events in Wallerian degeneration is recapitulated in this compartmental coculture system. After transection of myelinated axons in the side compartments, both the Schwann cells and neurons in culture respond to axotomy as observed in vivo. The only differences between the in vitro results and those seen in vivo are (as might be expected) within the time course of the responses. In our compartmental cultures, the first signs of myelin breakdown are seen as early as $6 \mathrm{~h}$. Schwann cell proliferation is initiated within $48 \mathrm{~h}$. Induction of c-jun protein in nerve cell bodies (Kenney and Kocsis, 1997) and degeneration of axons can be detected within $1 \mathrm{~h}$ and $24 \mathrm{~h}$, respectively. The corresponding times in transected rat sciatic nerves in vivo are somewhat longer $(\sim 12,72,12$, and $24 \mathrm{~h}$, respectively).
Transient activation of erbB2 is sufficient to initiate Schwann cell demyelination

Data summarized in Figure 4 suggest that transient activation of erbB2 (Fig. 1) is required to initiate axotomy-induced Schwann cell demyelination in vivo; however, the animal experiments do

\section{PKI166 inhibits Schwann cell demyelination after axotomy in vitro}

Having validated the compartmentalized neuron/Schwann cell cocultures as an in vitro model for Wallerian degeneration, we demonstrated that the role of erbB2 activation in the initial stages 
of Wallerian degeneration is localized to Schwann cells on the axons. When neuregulin is added to the side compartments (myelinated axons and Schwann cells), demyelination is induced. In contrast, addition of neuregulin to the middle compartment (neuronal soma) does not induce demyelination (Fig. 9A). The function of neuregulin on demyelination is likely to be attributable to its direct effect on Schwann cells, because neurons do not express erbB2 (Zanazzi et al., 2001).

Next, we tested the effect of PKI166 on injury-induced Schwann cell demyelination in the compartmental culture system described in Figure 7. In control cultures, PKI166 does not have any effect on intact myelinated axons. However, PKI166 inhibits Schwann cell demyelination in axons distal to a razor blade-induced axotomy (Fig. $9 B)$. Therefore, the anti-Wallerian effects of PKI166 observed in rats reflect a direct action of the drug on Schwann cells rather than some indirect action on other tissues in vivo.

\section{Discussion}

During Wallerian degeneration, Schwann cell responses are initiated by a positive signaling event that requires close contact with damaged axons (Kidd and Heath, 1991). Exposure to recombinant neuregulin in vitro can induce demyelination that mimics the early response of Schwann cells to nerve damage in animals (Zanazzi et al., 2001). However, the relationship of this neuregulin-induced response in cell culture to the demyelination induced by mechanical damage to axons has been unclear. Previous studies have shown that neuregulin receptors are activated only at late times in Wallerian degeneration (days 5-18) when demyelinated Schwann cells begin to proliferate. At these late times, activated erbB2 is visualized diffusely over the surface of reactive cells (Kwon et al., 1997).

Using high-resolution sampling intervals, deconvolving microscopy and phosphorylation state-specific antibodies, we describe a hitherto unappreciated, rapid - but transient - activation of erbB2. Activation emanates from within the microvilli of Schwann cells, in direct contact with the axons they enwrap. Experiments with the erbB2 antagonist PKI166 indicate that transient activation of erbB2 is required to initiate Wallerian degeneration both in vivo and in vitro. Pulse-chase experiments conducted in DRG/Schwann cell cocultures indicate that erbB2 activation is also sufficient to initiate Wallerian degeneration and may be required only within the first few hours of the response. In addition, the response of our compartmental cocultures to axotomy confirms a previous report that fibroblasts and macrophages are not the essential components of the initial phases of Wallerian degeneration (Fernandez-Valle et al., 1995).

The rapid but transient nature of the initial erbB2 response in vivo may reconcile a somewhat confusing and contradic-

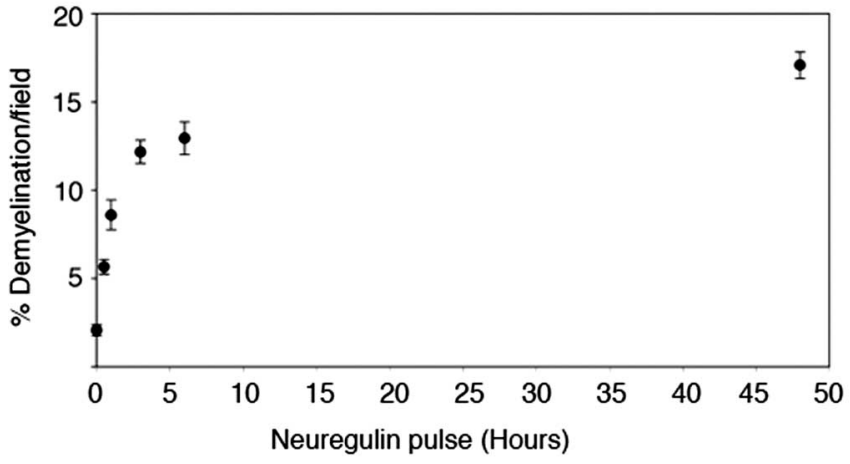

Figure 6. Neuregulin pulse-chase and Schwann cell demyelination in culture. Neuron/ Schwann cell cocultures that had myelinated for 4 weeks were treated with neuregulin (30 $\mathrm{ng} / \mathrm{ml}$ ) for various times (30 min, 1, 3, 6, and $48 \mathrm{~h}$ ), and the culture medium was removed. Cultures were washed with PBS and then incubated continually in fresh medium for the remainder of the experimental period ( $48 \mathrm{~h}$ ). Cultures were fixed and immunostained for MBP and scored for demyelination. The mean values and SEM presented for each data point are from at least 80 random fields pooled from a representative experiment. Similar results were observed in triplicate independent experiments.

A.

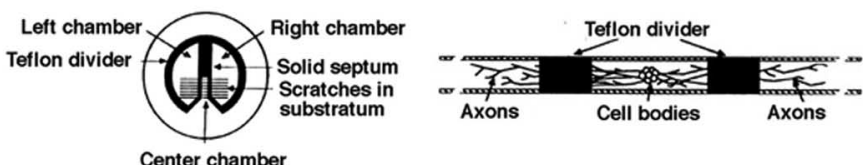

B.

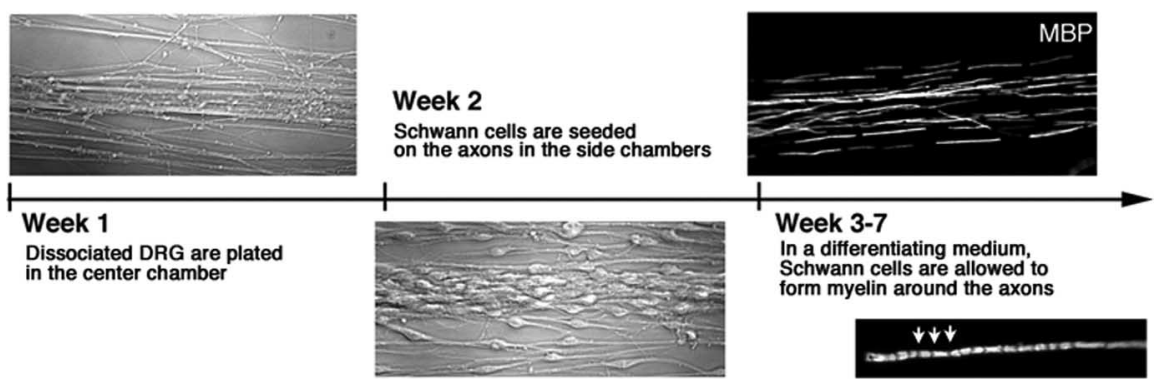

Figure 7. Construction of an in vitro model for Wallerian degeneration using a compartmentalized culture system. $\boldsymbol{A}$, Compartmental culture chambers. The culture is comprised of three compartments, two side chambers, and a center chamber, separated by silicon- grease-sealed Teflon dividers. DRG sensory neurons are plated in the center compartment, and the axons grow across the divider along the tracks made on the collagen-coated plastic surface. [The illustration is adapted from the study by Campenot and Martin (2001).] B, Formation of myelinated nerves in compartmental cultures. Within 1 week of plating DRG neurons into the center compartment, axons have grown into the side compartments in parallel arrays. At week 2, Schwann cells are plated onto axons in the side chambers. Three to 4 weeks after plating of Schwann cells, myelinated segments on axons are visible by immunostaining using MBP antibodies. Inset, A higher magnification of a myelinating Schwann cell in culture. Schmidth-Lantermann incisors are visible in the internode (arrows). 
A.

Myelin break down
Schwann cell Proliteration
c.jun induction
Axonal degeneration
Functional recovery

B. Myelin break down (MBP)
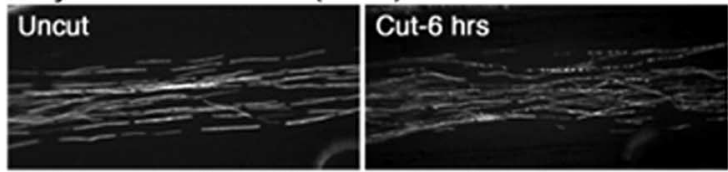

C. Schwann cell proliferation (BrdU)
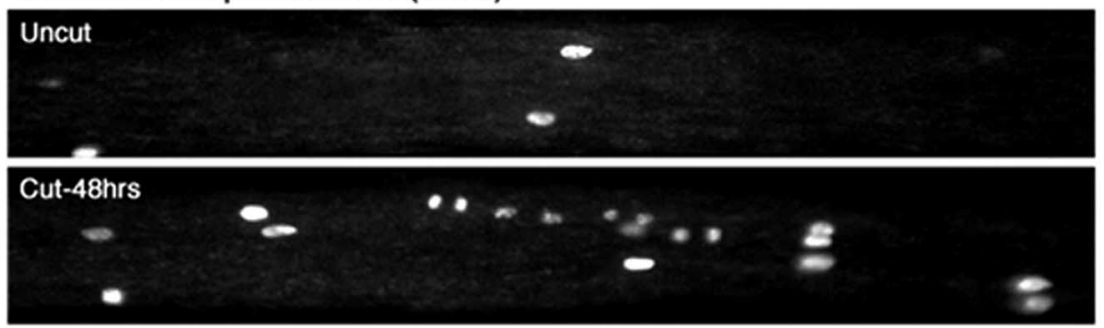

D. c-jun induction (neuronal cell bodies)

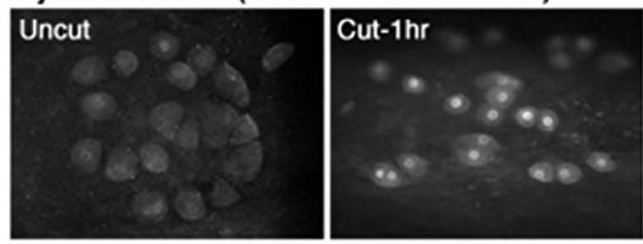

E. Axon degeneration ( $\beta$ III-tubulin)
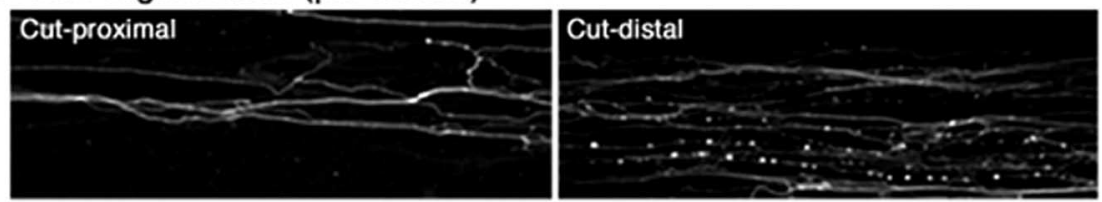

Figure 8. Wallerian degeneration in vitro. $\boldsymbol{A}$, Time line of Wallerian degeneration in rats. See Results for details. $\boldsymbol{B}-\boldsymbol{E}$, Wallerian degeneration in culture. Myelinated axons were cut using a razor blade to mimic nerve injury. $\boldsymbol{B}$, Demyelination in Schwann cells as visualized by immunostaining of the cultures using antibody to MBP. Demyelination in response to nerve injury is detected within $6 \mathrm{~h}$ and is well advanced at $24 \mathrm{~h}$. C, Schwann cell proliferation after nerve damage. At $48 \mathrm{~h}$ after axotomy, Schwann cells that were formerly in contact with axons began to proliferate as shown by linear arrays of BrdU-positive cells. D, Neuronal responses. Within $1 \mathrm{~h}$ after axotomy, the immediate-early gene c-jun protein is visible within the nerve cell bodies in the middle compartment. $\boldsymbol{E}$, Axonal degeneration in vitro. Within $24 \mathrm{~h}$ after axotomy, axons (visualized by immunostaining for $\beta$-III tubulin) are distal to the cut degenerate, whereas the proximal axons remain intact. tory body of previous work on the role of erbB2 and MAPK in nerve regeneration. The serine/threonine protein kinase MAPK is well known to be a downstream effector of erbB2 or erbB3 activation (Marte et al., 1995; Sepp-Lorenzino et al., 1996; Carroll et al., 1997; Grasso et al., 1997; Pinkas-Kramarski et al., 1998; Baliga et al., 1999). In cultured Schwann cells, activation of MAPK negatively regulates the level of Schwann cell differentiation, whereas activation of phosphatidylinositol 3-kinase pathways promotes it (Ogata et al., 2004). Other workers have shown recently that MAPK is activated within $24 \mathrm{~h}$ after nerve injury (Sheu et al., 2000; Harrisingh et al., 2004). However, they noted (correctly) that a 24 -h activation response would place MAPK upstream rather than downstream of erbB2 because published reports showed erbB2 activation at much later times (Kwon et al., 1997). As we show here, MAPK is actually activated within 20 min after axotomy, presumably as a consequence of the initial transient activation of erbB2.

The duration of MAPK activation exceeds that of the initial erbB2 response when the activation state of erbB2 is measured by immunoblot assays (Fig. 1). However, activations of MAPK and erbB2 are in good accord when erbB2 activity is assessed at the cellular level by immunostaining with phosphospecific antibodies. The more prolonged activation of erbB2 seen at the cellular level may reflect the ability of phosphospecific antibodies to see low levels of activated erbB2 that are highly concentrated at the paranode.
The epidermal growth factor receptor (EGFR) is another member of the erbB family of receptor tyrosine kinases. Lowlevel expression of EGFR in sciatic nerve, presumably in Schwann cells and fibroblasts, has been reported. Surgical transection of rat sciatic nerve upregulates EGFR expression in Schwann cells within $72 \mathrm{~h}$ after the injury. However, the activation state of EGFR during Wallerian degeneration is not known (Toma et al., 1992). It should be noted that PKI166 is a dual EGFR/erbB2 tyrosine kinase inhibitor with $\mathrm{IC}_{50}$ values in a similar range for both receptors (Traxler et al., 2001). Accordingly, if EGFR actually does contribute to Wallerian degeneration, the inhibitory effect of PKI166 on the Schwann cell response to nerve injury might reflect, in part, the inhibition of EGFR activation.

The mechanism of axotomy-induced erbB2 activation is not known. The simplest and most plausible explanation is that one or more of the splice isoforms of neuregulin that are known to be expressed in nerves with long axons is released on nerve injury. For instance, SMDF (sensory and motor neuron-derived factor), a member of neuregulin family ligands, can be cleaved and released into the environment (Rosenbaum et al., 1997; Schroering and Carey, 1998). Transgenic mice overexpressing GGF $\beta$-3 (glial growth factor $\beta$-3) develop neuropathies and Schwann cell hyperplasia in adult nerves (Huijbregts et al., 2003), indicating that GGF $\beta$-3 expression might be involved in inducing demyelination and proliferation of Schwann cells in adult nerve after nerve injury. It is less likely, but also formally possible, that injury to the 

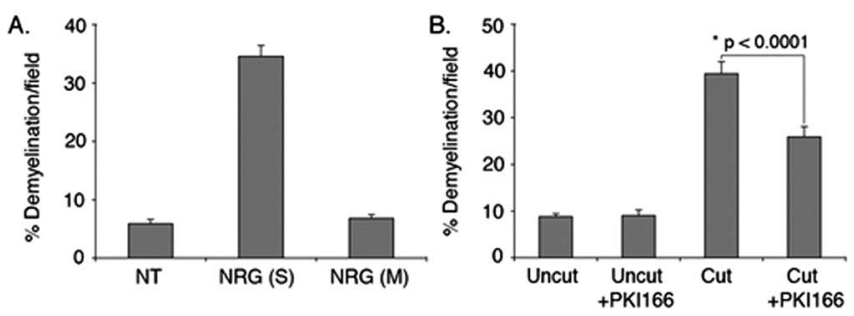

Figure 9. Neuregulin-induced demyelination is a localized effect on Schwann cells. Neuron/ Schwann cell cocultures in the compartmentalized culture system had myelinated for 4 weeks. A, Neuregulin $(30 \mathrm{ng} / \mathrm{ml})$ was added to Schwann cells in the side compartments $(S)$ or to neuronal soma in the middle compartment (M). Forty-eight hours later, cultures were fixed and immunostained for MBP. A significant increase in demyelination was detected when neuregulin was added to the side compartments but not in the middle compartment compared with the cultures left untreated (NT). The mean values and SEM presented for each data point are from at least 80 random fields pooled from a representative experiment. Similar results were observed in duplicate independent experiments. $\boldsymbol{B}$, Myelinated axons in the side compartments were pretreated with PKI166 $(3 \mu \mathrm{M})$ for 20 min followed by a cut to the axons using a razor blade. Twenty-four hours later, cultures were processed for immunostaining as in $A$. Axotomy-induced Schwann cell demyelination was significantly inhibited by PKI166. The mean values and SEM were calculated from three independent experiments with each experiment containing data obtained from at least 30 random fields. *Statistical significance was determined by ANOVA test.

nerve activates erbB2 in a ligand-independent manner, perhaps by inhibition of receptor tyrosine phosphatases within the Schwann cells (Ostman and Bohmer, 2001). Ions such as calcium might be involved in this process, and, on this note, calcium influx in the nodal region of Schwann cells after nerve injury has been reported (Schlaepfer, 1977; Schlaepfer and Hasler, 1979). Any future insights into the activation mechanism will have to account for the rapid rate at which the damage signal is propagated through the distal stump. We observed that, within $1 \mathrm{~h}$ after axotomy, erbB2 is equally activated in Schwann cells adjacent to and $2 \mathrm{~cm}$ distal to the nerve cut injury (data not shown).

What is the cellular fate of erbB2 after activation at the Schwann cell microvilli? Activated receptor tyrosine kinases are taken into the cell cytosol via receptor-mediated endocytosis. In cells that are small (fibroblasts, lymphocytes), the internalized receptors undergo one of two fates - proteolytic degradation or local recycling. However, in nerve cells with long axons, internalized neurotrophin receptors have a third option. Activated neurotrophin receptors form a vesicle-associated signal-generating complex ("signaling endosome") that is physically relocalized to the nerve cell body by rapid, motor-driven retrograde transport (Watson et al., 1999; Kuruvilla et al., 2000; Howe et al., 2001). The microvilli of a myelinating Schwann cell represent an anatomical "middle ground" between the plasma membrane of a small cell and the synaptic terminal of a long axon. Accordingly, local recycling, proteolytic degradation, or vesicle-mediated translocation to the Schwann cell body would all appear to be viable options. The punctate appearance of p-erbB2 staining at the outer membrane after nerve injury might indicate the involvement of vesicle-mediated transport of activated erbB2 from the microvilli to the cell body of a myelinating Schwann cell (Fig. 3).

Although these interesting questions are currently unresolved, the studies summarized here do shed some light on the microanatomy of axon/glia signaling. Myelinating Schwann cells have two bioactive membrane surfaces. The outer cell surface has better access to growth factors and hormones in blood and interstitial fluid. The inner cell surface makes direct contact with the axon. It appears that a dialogue between axons and receptor ty- rosine kinases in myelinating Schwann cells is enabled by placing the receptors in direct contact with the axons that they enwrap.

\section{References}

Baliga RR, Pimental DR, Zhao YY, Simmons WW, Marchionni MA, Sawyer DB, Kelly RA (1999) NRG-1-induced cardiomyocyte hypertrophy. Role of PI-3-kinase, $\mathrm{p} 70^{\mathrm{S} 6 \mathrm{~K}}$, and MEK-MAPK-RSK. Am J Physiol 277:H2026-H2037.

Britsch S, Li L, Kirchhoff S, Theuring F, Brinkmann V, Birchmeier C, Riethmacher D (1998) The ErbB2 and ErbB3 receptors and their ligand, neuregulin-1, are essential for development of the sympathetic nervous system. Genes Dev 12:1825-1836.

Brockes JP, Fields KL, Raff MC (1979) Studies on cultured rat Schwann cells. I. Establishment of purified populations from cultures of peripheral nerve. Brain Res 165:105-118.

Buonanno A, Fischbach GD (2001) Neuregulin and ErbB receptor signaling pathways in the nervous system. Curr Opin Neurobiol 11:287-296.

Burden S, Yarden Y (1997) Neuregulins and their receptors: a versatile signaling module in organogenesis and oncogenesis. Neuron 18:847-855.

Campenot RB (1977) Local control of neurite development by nerve growth factor. Proc Natl Acad Sci USA 74:4516-4519.

Campenot RB (1982) Development of sympathetic neurons in compartmentalized cultures. II. Local control of neurite survival by nerve growth factor. Dev Biol 93:13-21.

Campenot RB, Martin G (2001) Construction and use of compartmented cultures for studies of cell biology of neurons. In: Protocols for neural cell culture, Ed 3 (Federoff S, Richardson A, eds), pp 49-57. Totowa, NJ: Humana.

Carroll SL, Miller ML, Frohnert PW, Kim SS, Corbett JA (1997) Expression of neuregulins and their putative receptors, ErbB2 and ErbB3, is induced during Wallerian degeneration. J Neurosci 17:1642-1659.

Eccleston PA, Funa K, Heldin C-H (1993) Expression of platelet-derived growth factor (PDGF) and PDGF $\alpha$-and $\beta$-receptors in the peripheral nervous system: an analysis of sciatic nerve and dorsal root ganglia. Dev Biol 155:459-470.

Einheber S, Zanazzi G, Ching W, Scherer S, Milner TA, Peles E, Salzer JL (1997) The axonal membrane protein Caspr, a homologue of neurexin IV, is a component of the septate-like paranodal junctions that assemble during myelination. J Cell Biol 139:1495-1506.

Eldridge CF, Bunge MB, Bunge RP, Wood PM (1987) Differentiation of axon-related Schwann cells in vitro. I. Ascorbic acid regulates basal lamina assembly and myelin formation. J Cell Biol 105:1023-1034.

Esper RM, Loeb JA (2004) Rapid axoglial signaling mediated by neuregulin and neurotrophic factors. J Neurosci 24:6218-6227.

Falls DL (2003) Neuregulins: functions, forms, and signaling strategies. Exp Cell Res 284:14-30.

Fawcett JW, Keynes RJ (1990) Peripheral nerve regeneration. Annu Rev Neurosci 13:43-60.

Fernandez-Valle C, Bunge RP, Bunge MB (1995) Schwann cells degrade myelin and proliferate in the absence of macrophages: evidence from in vitro studies of Wallerian degeneration. J Neurocytol 24:667-679.

Glass JD, Brushart TM, George EB, Griffin JW (1993) Prolonged survival of transected nerve fibres in C57BL/Ola mice is an intrinsic characteristic of the axon. J Neurocytol 22:311-321.

Grasso AW, Wen D, Miller CM, Rhim JS, Pretlow TG, Kung HJ (1997) ErbB kinases and NDF signaling in human prostate cancer cells. Oncogene 15:2705-2716.

Hardy M, Reddy UR, Pleasure D (1992) Platelet-derived growth factor and regulation of Schwann cell proliferation in vivo. J Neurosci Res 31:254-262.

Harrisingh MC, Perez-Nadales E, Parkinson DB, Malcolm DS, Mudge AW, Lloyd AC (2004) The Ras/Raf/ERK signalling pathway drives Schwann cell dedifferentiation. EMBO J 23:3061-3071.

Ho WH, Armanini MP, Nuijens A, Phillips HS, Osheroff PL (1995) Sensory and motor neuron-derived factor. A novel heregulin variant highly expressed in sensory and motor neurons. J Biol Chem [Erratum (1995) 270:26722] 270:14523-14532.

Howe CL, Valletta JS, Rusnak AS, Mobley WC (2001) NGF signaling from clathrin-coated vesicles: evidence that signaling endosomes serve as a platform for the Ras-MAPK pathway. Neuron 32:801-814.

Huijbregts RP, Roth KA, Schmidt RE, Carroll SL (2003) Hypertrophic neuropathies and malignant peripheral nerve sheath tumors in transgenic 
mice overexpressing glial growth factor $\beta 3$ in myelinating Schwann cells. J Neurosci 23:7269-7280.

Kenney AM, Kocsis JD (1997) Timing of c-jun protein induction in lumbar dorsal root ganglia after sciatic nerve transection varies with lesion distance. Brain Res 751:90-95.

Kidd GJ, Heath JW (1991) Myelin sheath survival following axonal degeneration in doubly myelinated nerve fibers. J Neurosci 11:4003-4014.

Kuruvilla R, Ye H, Ginty DD (2000) Spatially and functionally distinct roles of the PI3-K effector pathway during NGF signaling in sympathetic neurons. Neuron 27:499-512.

Kwon YK, Bhattacharyya A, Alberta JA, Giannobile WV, Cheon K, Stiles CD, Pomeroy SL (1997) Activation of ErbB2 during Wallerian degeneration of sciatic nerve. J Neurosci 17:8293-8299.

Marchionni MA (1995) Cell-cell signalling. neu tack on neuregulin. Nature 378:334-335.

Marchionni MA, Goodearl AD, Chen MS, Bermingham-McDonogh O, Kirk C, Hendricks M, Danehy F, Misumi D, Sudhalter J, Kobayashi K, Wroblewski D, Lynch C, Baldassare M, Hiles I, Davis JB, Hsuan JJ, Totty NF, Otsu M, McBurney RN, Waterfield MD, et al. (1993) Glial growth factors are alternatively spliced erbB2 ligands expressed in the nervous system. Nature 362:312-318.

Marte BM, Graus-Porta D, Jeschke M, Fabbro D, Hynes NE, Taverna D (1995) NDF/heregulin activates MAP kinase and p70/p85 S6 kinase during proliferation or differentiation of mammary epithelial cells. Oncogene 10:167-175.

Melendez-Vasquez CV, Rios JC, Zanazzi G, Lambert S, Bretscher A, Salzer JL (2001) Nodes of Ranvier form in association with ezrin-radixin-moesin (ERM)-positive Schwann cell processes. Proc Natl Acad Sci USA 98:1235-1240.

Menegoz M, Gaspar P, Le Bert M, Galvez T, Burgaya F, Palfrey C, Ezan P, Arnos F, Girault JA (1997) Paranodin, a glycoprotein of neuronal paranodal membranes. Neuron 19:319-331.

Meyer D, Birchmeier C (1995) Multiple essential functions of neuregulin in development. Nature [Erratum (1995) 378:753] 378:386-390.

Meyer D, Yamaai T, Garratt A, Riethmacher-Sonnenberg E, Kane D, Theill LE, Birchmeier C (1997) Isoform-specific expression and function of neuregulin. Development 124:3575-3586.

Michailov GV, Sereda MW, Brinkmann BG, Fischer TM, Haug B, Birchmeier C, Role L, Lai C, Schwab MH, Nave KA (2004) Axonal neuregulin-1 regulates myelin sheath thickness. Science 304:700-703.

Morris JK, Lin W, Hauser C, Marchuk Y, Getman D, Lee KF (1999) Rescue of the cardiac defect in ErbB2 mutant mice reveals essential roles of ErbB2 in peripheral nervous system development. Neuron 23:273-283.

Ogata T, Iijima S, Hoshikawa S, Miura T, Yamamoto S, Oda H, Nakamura K, Tanaka S (2004) Opposing extracellular signal-regulated kinase and Akt pathways control Schwann cell myelination. J Neurosci 24:6724-6732.

Ostman A, Bohmer FD (2001) Regulation of receptor tyrosine kinase signaling by protein tyrosine phosphatases. Trends Cell Biol 11:258-266.

Pinkas-Kramarski R, Shelly M, Guarino BC, Wang LM, Lyass L, Alroy I, Alimandi M, Kuo A, Moyer JD, Lavi S, Eisenstein M, Ratzkin BJ, Seger R, Bacus SS, Pierce JH, Andrews GC, Yarden Y, Alamandi M (1998) ErbB tyrosine kinases and the two neuregulin families constitute a ligandreceptor network. Mol Cell Biol [Erratum (1998) 18:7602] 18:6090-6101.

Rosenbaum C, Karyala S, Marchionni MA, Kim HA, Krasnoselsky AL, Hap- pel B, Isaacs I, Brackenbury R, Ratner N (1997) Schwann cells express NDF and SMDF/n-ARIA mRNAs, secrete neuregulin, and show constitutive activation of erbB 3 receptors: evidence for a neuregulin autocrine loop. Exp Neurol 148:604-615.

Scherer SS, Xu T, Crino P, Arroyo EJ, Gutmann DH (2001) Ezrin, radixin, and moesin are components of Schwann cell microvilli. J Neurosci Res 65:150-164.

Schlaepfer WW (1977) Structural alterations of peripheral nerve induced by the calcium ionophore A23187. Brain Res 136:1-9.

Schlaepfer WW, Hasler MB (1979) Characterization of the calciuminduced disruption of neurofilaments in rat peripheral nerve. Brain Res 168:299-309.

Schroering A, Carey DJ (1998) Sensory and motor neuron-derived factor is a transmembrane heregulin that is expressed on the plasma membrane with the active domain exposed to the extracellular environment. J Biol Chem 273:30643-30650.

Sepp-Lorenzino L, Eberhard I, Ma Z, Cho C, Serve H, Liu F, Rosen N, Lupu R (1996) Signal transduction pathways induced by heregulin in MDA-MB453 breast cancer cells. Oncogene 12:1679-1687.

Sheu JY, Kulhanek DJ, Eckenstein FP (2000) Differential patterns of ERK and STAT3 phosphorylation after sciatic nerve transection in the rat. Exp Neurol 166:392-402.

Thomson CE, Mitchell LS, Griffiths IR, Morrison S (1991) Retarded Wallerian degeneration following peripheral nerve transection in C57BL/6/Ola mice is associated with delayed down-regulation of the $\mathrm{P} 0$ gene. Brain Res 538:157-160.

Toma JG, Pareek S, Barker P, Mathew TC, Murphy RA, Acheson A, Miller FD (1992) Spatiotemporal increases in epidermal growth factor receptors following peripheral nerve injury. J Neurosci 12:2504-2515.

Traxler P, Bold G, Buchdunger E, Caravatti G, Furet P, Manley P, O'Reilly T, Wood J, Zimmermann J (2001) Tyrosine kinase inhibitors: from rational design to clinical trials. Med Res Rev 21:499-512.

Vartanian T, Goodearl A, Viehover A, Fischbach G (1997) Axonal neuregulin signals cells of the oligodendrocyte lineage through activation of HER4 and Schwann cells through HER2 and HER3. J Cell Biol 137:211-220.

Waller A (1851) Experiments on the section of the glosso-pharyngeal and hypoglossal nerves of the frog, and observations of the alterations produced thereby in the structures of their primitive fibres. Edinburgh Med Surg J 76:369-376.

Wang JY, Miller SJ, Falls DL (2001) The N-terminal region of neuregulin isoforms determines the accumulation of cell surface and released neuregulin ectodomain. J Biol Chem 276:2841-2851.

Watson FL, Heerssen HM, Moheban DB, Lin MZ, Sauvageot CM, Bhattacharyya A, Pomeroy SL, Segal RA (1999) Rapid nuclear responses to target-derived neurotrophins require retrograde transport of ligandreceptor complex. J Neurosci 19:7889-7900.

Woldeyesus MT, Britsch S, Riethmacher D, Xu L, Sonnenberg-Riethmacher E, Abou-Rebyeh F, Harvey R, Caroni P, Birchmeier C (1999) Peripheral nervous system defects in erbB2 mutants following genetic rescue of heart development. Genes Dev 13:2538-2548.

Zanazzi G, Einheber S, Westreich R, Hannocks MJ, Bedell-Hogan D, Marchionni MA, Salzer JL (2001) Glial growth factor/neuregulin inhibits Schwann cell myelination and induces demyelination. J Cell Biol 152: $1289-1299$. 